\title{
90 YEARS OF PROFESSOR JEAN NICOD
}

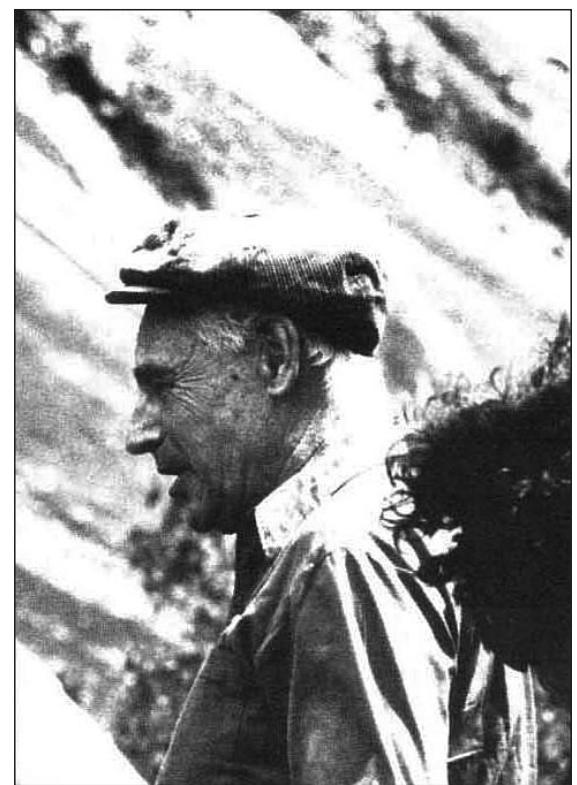

Prof. Jeani Nicod in the field, 1992.

Jean Nicod Dr. Litt., retired Professor Emeritus of Physical Geography at the University Aix-Marseille II, Institute of Geography, Aix-en-Provence, Doctor Honoris Causa of Silesian University, and corresponding member of the Slovenian Academy of Sciences and Arts was born 90 years ago at Vesoul, Haute-Saône Department (France), not far away from karst plateaux of Jura. Already as a pupil of the Vesoul secondary school (up to 1940) he was diligently visiting caves in the surroundings of the town. He studied at the Faculty of Arts of the University of Nancy (1941-1944) and for the "Diplôme d'Etudes supérieures" he described karst phenomena of the Haute-Saône plateaux. In 1944 he became Master of Geography and after state's examinations he obtained the title of "Professeur Agrégé de Géographie" (1947). As a teacher at the Lycée de Marseille he started with Professor Jules Blache to prepare the thesis on "The Karst Morphology of the Limestone Basse Provence". Meanwhile he was teaching at secondary schools at Nancy and Marseilles, he worked as a researcher of C.N.R.S. (National Centre of Scientific Research, 1953-55), as the head of the Regional Centre for Pedagogical Documentation at Marseilles, and as the assistant, later master-assistant at Faculties of Aix-en-Provence and Nice. In 1967 he obtained the state's doctorate. Throughout the years to his retirement he was teaching at the universities of Marseille and Aix-en-Provence.

In his thesis on "The Karst Morphology of the Limestone Basse Provence" he proved the existence of various types of karst, from Calanques to Grand Canyon of Verdon and presented hydrochemical observations as a tool to measure the rate of denudation. During his long career as a university teacher he emphasized the problems of the karst of South-East France, during teaching courses as well as during his field work. Prof. Nicod was the founder and the director of the main karst project of France, "Karst evolution in Mediterranean and Alpine environments" in the frame of C.N.R.S. (1971-1983). This project enabled the founding of the group "Procope" together with Prof. Pfeffer (Tübingen); the main aim of this collaboration was intended to study erosion and alteration of dolomite. Prof. Nicod was the president of the Karst Phenomena Commission of the National Committee of Geography and of the French Karstological Association (1977-1986). He was initiator and long-time co-worker of the leading French karstological journal Karstologia and the journal Méditerranée, in admiration of his research work these journals have named Prof. Nicod an honorary president and an honorary member, respectively.

Most of Prof. Nicod's professional work is oriented towards karst regions of Provence and karst of France, but not exclusively. As a karstologist and geographer he dedicated his life's work to karst in a very broad sense, namely to geomorphology, geomorphological mapping, evaporite karst, karst canyons, alteration of dolomite, cryptokarstic corrosion, palaeokarst, glaciokarst, tuffa, poljes, calanques, hydrological regimes, forests, forest 
fires, traffic, olives, and water energy on karst. He was investigating the karst problems in the area of Mediterranean, including Dinaric Karst and karst of the Near East. Special attention has to be paid to his research conducted in Slovenia and Croatia, his research on poljes in Dinaric Karst and in Eastern Serbia, and of Durmitor Mountains.

It can be said that the beginning of close contacts between Prof. Nicod's group of young karstologists and Slovenian ones started with a brief but important visit of the author of these lines to Prof. Nicod at Aix-en-Provence that included the observations of some of the most impressive parts of the karst of Provence. The co-operation was formalized through research institutions in 1975, later in the frame of the programme Proteus. Prof. Nicod organized the series of bilateral round-tables on karst, Franco-Slovene in 1991. For these achievements he received the award of the former Slovenian Ministry of Science and Technology. In a large number of his numerous publications on karst he is describing Dinaric Karst and there are about 20 papers that he dedicated exclusively to the Dinaric karst, some of them published by Slovenian journals. Here I would like to specially mention his book "Les karsts dinariques, paysages et problèmes" (Dinaric Karst, landscapes and problems) published in 2003 in collaboration with the Karst Research Institute ZRC SAZU at Postojna; additionally he was the editor of the journal Karstologia. Slovenian karstologists have to be thankful to Prof. Nicod for enabling contacts and mutual visits of Slovenian and French colleagues, for the invitations to numerous international meetings, for visits to and explanations of French karst from many points of view and for keeping them informed on novelties from French karstological spheres as well as karstological achievements of Slovenian researchers, for publishing adequate Slovenian literature, and for reports on various karstological events in Slovenia, all of these being of great importance for the promotion of Slovenian karstology. On the other side it is French karst which is among the most important in Europe and therefore also well known by Slovenian karstologists; this can be seen very well via the influence of French specialists obvious in many publications of Slovenian researchers. And all these achievements are in a major part due to the influence and work of Prof. Nicod. These are also the reasons that Prof. Nicod was named an honorary member of the Association of Slovenian Geographers.

To conclude it is important to stress that Prof. Nicod is being a member of the Editorial Board of this journal, Acta carsologica, for many years already. Recently (2012) he has published the book "Sources et sites des eaux karstiques" (Karst Water Springs and Sites) and in the name of the Editorial Board and also in the name of all karstologists - his friends in Slovenia (I am convinced about it), we are wishing Prof. Nicod to continue to share his immense knowledge on karst with the World's karstological community.

Andrej Kranjc 